\title{
Remediation of Crude Oil-Polluted Soil with Lime
}

\author{
Anyadike, C.C., Akunne, I., Ugwuishiwu, B.O., Ajah, G.N., Ogwo, V.I., \\ ${ }^{1}$ (Department of Agricultural and Bioresources Engineering, University of Nigeria, Nsukka, Nigeria) \\ ${ }^{2}$ (Department of Agricultural and Bioresources Engineering,University of Nigeria, Nsukka, Nigeria) \\ ${ }^{3}$ (Department of Agricultural and Bioresources Engineering,University of Nigeria, Nsukka, Nigeria) \\ ${ }^{4}$ (Department of Electrical Engineering,University of Nigeria, Nsukka, Nigeria) \\ 5 (Department of Agricultural and Bioresources Engineering,University of Nigeria, Nsukka, Nigeria)
}

\begin{abstract}
Research was carried out to assess the damage caused by oil spills on agricultural land. In order to remove oil contamination in the soil, it was treated with lime for toxicity reduction. Soil $\mathrm{pH}$ was slightly acidic and ranged from 5.5 to 6.0. Fertilizer was applied for soil replenishment and to increase production.
\end{abstract}

Keywords: - Remediation, hydro-carbon, Lime, Oil, Soil.

\section{INTRODUCTION}

Oil spills and pollution have been a regular occurrence, of which $2.1 \%$ is from offshore oil production operations, $1.4 \%$ from tank barges, $28.4 \%$ from tankers, $17.3 \%$ other vessels, $6.1 \%$ from refinery/petrochemical plant disposal, $15.3 \%$ industry/machine waste oil and $29.4 \%$ due to improper disposal of automobile crank case oil disposed [1]. Recently the Federal Government and foreign oil companies have begun to take steps to mitigate the damage [2]. The harmful effects of oil spill and pollution on the environment are many and cannot be over emphasized. In all cases, natural phenomenon like spreading, dispersion, emulsification, oxidation and sedimentation combine to change the characteristics of the spilled oil. Oil spills reaching shoreline however, causes mortality of marine organisms, birds, mammals, fishes and disrupts major food chains. In a bid to clean oil spills by the use of oil dispersants, toxic effects will be exerted on plankton thereby poisoning marine animals. This can further lead to food poisoning and loss of lives.

Research studies show that the disappearance of crude oil from sea water could be accelerated by the addition of deficient nutrient such as nitrogen, phosphorus or both. Suggestions have been made for microbial seeding of oil spills since bacteria and fungi are the only biological species which have the metabolic capacity of utilizing petroleum carbon for cell synthesis.

It has been observed that oil spills result in an imbalance in the carbon-nitrogen $(\mathrm{C} / \mathrm{N})$ ratio at the spill site because crude oil is essentially a mixture of carbon and hydrogen. This causes a nitrogen deficiency in an oil-soaked soil which retards the growth of bacteria and the utilization of carbon sources. In addition to a nitrogen deficiency in an oil-soaked soil, certain nutrients like phosphorus may be growth-rate limiting. Furthermore a large amount of biodegradable organics in the top layers of soils depletes oxygen reserves in the soil and slows down the rate of oxygen diffusion to the deeper layer [2].

Sequel to the above, crude oil pollution persists in soils until remediation measures involving the manipulation of these parameters are resorted to, since oxygen and nitrogen are limiting factors in all types of petroleum degradation. The spillage of crude oil on the land contributes to the blocking of the soil micro and macro pores, thereby hindering soil aeration and water infiltration. Hence, the aim of this study is to evaluate the extent of damage done by the oil pollution on the agricultural soil and possible ways of reclamation.

\section{METHODOLOGY}

The study was carried out from June to August, 2005. The soil was divided into four (5) treatment cells that were made into beds each with dimensions $40 \mathrm{~cm} \times 40 \mathrm{~cm} \times 30 \mathrm{~cm}$ with exposed surface area such that temperature, nutrient concentration, moisture content and oxygen availability can be controlled. The beds also served to prevent excessive run-off of the crude oil contaminant amidst the rains.

Cell 0 was the control without any treatments, Cells A, B, C and D were earmarked to receive $50 \mathrm{~g}, 75 \mathrm{~g}$, $100 \mathrm{~g}$ and $150 \mathrm{~g}$ of 20-10-10 NPK fertilizer respectively twice during the remediation period at two weeks interval. Prior to fertilizer application, $800 \mathrm{~cm}^{3}(0.8 \mathrm{~L})$ of Bonny light crude

(http://en.wikipedia.org/wiki/Bonny_Light_oil) was applied to the cells (including control) by sprinkling from perforated cans at the rate of $0.8 \mathrm{~L}$ of crude oil per $0.16 \mathrm{~m}^{2}$ of soil till it completely covered the surface of the cells with a thin layer of oil. The objective was to stimulate conditions of a major spill. The cells were left undisturbed for three days. 


\subsection{Soil Sampling}

Different random spots were augured using a 9-inch auger capable of obtaining uniform cores of equal volume to the desired depths. Composite soil samples were bucked together and stored in labeled polyethylene bags. The samples for total hydrocarbon content (THC) measurements were placed in $1 \mathrm{~L}$ glass bottles and sealed with aluminum foils. Three replicates were produced. All the test materials were immediately transferred for analysis.

\subsection{Soil Treatments}

Lime was used as treatment to reduce toxic deposition on the soil, fertlizers such as NPK at 15, 15, 15 was used to replenish the soil nutrients, tetrachloromethane and benzene as solvent was used for soil treatment. Soil physicochemical parameter such as particle size distribution, THC, organic carbon (OC), total nitrogen, moisture, moisture content, soil $\mathrm{pH}$, electrical conductivity (EC), microbial analysis/bacteria count were determined using methods adapted from relevant literatures. Particle size analysis was performed by the Bouyoucous hydrometer method [3]. THC was carried out using the procedure described by Odu et al (1985) while organic carbon was determined by the combustion method of Walky and Black (1934), total nitrogen, moisture content and soil $\mathrm{pH} /$ electrical conductivity were determined using methods adapted from Odu et al., (1983), Smith and Smith (1998) and Jackson (1964), respectively. [4,5,6,7]

\section{RESULTS AND DISCUSSION}

Soil physicochemical characteristics are presented on Table 1 before crude oil contamination. The results were based on (i) chemical properties of the soil, (ii) soil test using tetra-chloromethane, (iii) Soil test using benzene

Table 1. Soil Physicochemical Characteristics before crude oil contamination

\begin{tabular}{|l|l|l|l|l|l|l|l|}
\hline Sand $(\mathrm{g})$ & $\begin{array}{l}\text { Moisture } \\
(\%)\end{array}$ & $\mathrm{pH}$ & $\mathrm{EC}(\mathrm{ns} / \mathrm{cm})$ & $\begin{array}{l}\mathrm{THC} \\
(\mathrm{mg} / \mathrm{Kg})\end{array}$ & OC & Total N & C/N ratio \\
\hline 10 & 13 & 5.7 & 2.8 & 84 & 0.19 & 0.38 & 0.5 \\
\hline
\end{tabular}

After 3 days, analysis was carried out on soil samples harvested and the results are presented in Table 2.

Table 2. Soil Physicochemical characteristics 3 days after contamination

\begin{tabular}{|l|l|l|l|l|l|l|l|}
\hline Cell & Moisture $(\%)$ & $\mathrm{pH}$ & $\mathrm{EC}(\mathrm{ns} / \mathrm{cm})$ & THC $(\mathrm{mg} / \mathrm{Kg})$ & $\mathrm{OC}$ & Total N & $\mathrm{C} / \mathrm{N}$ \\
\hline $\mathrm{O}$ & 5 & 4.7 & 20 & 980 & 0.12 & 0.1 & 0.5 \\
\hline $\mathrm{A}$ & 10 & 5.8 & 25 & 1,000 & 0.15 & 0.20 & 0.5 \\
\hline $\mathrm{B}$ & 12 & 6.0 & 26 & 1,100 & 0.20 & 0.19 & 0.5 \\
\hline $\mathrm{C}$ & 14 & 7.0 & 30 & 1,500 & 0.22 & 0.20 & 0.5 \\
\hline $\mathrm{D}$ & 17 & 7.0 & 50 & 1,300 & 0.30 & 0.21 & 0.5 \\
\hline
\end{tabular}

To minimize errors in measurement different $\mathrm{pH}$ measurement were obtained using different instruments to find out variations in $\mathrm{pH}$ as presented in Table 3 below.

Table 3. $\mathrm{pH}$ for limed and unlimed soils using different measuring instruments

\begin{tabular}{|l|l|l|}
\hline Instrument & pH of Unlimed soil & pH of Limed soil \\
\hline Soil lab bench $\mathrm{pH}$ meter & 5.6 & 6.8 \\
\hline Hand-held pH meter & 5.5 & 6.5 \\
\hline Colour kit & 5.8 & 7.0 \\
\hline Moni pH probe & 6.0 & 6.0 \\
\hline
\end{tabular}

Mean $\mathrm{pH}$ was evaluated and found to be 5.7 for unlimed soil and 6.5 for limed soil From Table 2, it can be observed that the soil samples contaminated with crude oil had higher THC and organic C compared with the control cell. Total nitrogen in all soil samples is reduced and this implies poor soil for crop production.

$300 \mathrm{Kg}$ of lime was added to the polluted soil to reduce toxicity and application of $450 \mathrm{Kg}$ of fertilizer per hectare was added for replenishing soil nutrients lost due to contamination with crude oil. Tetrachloromethane and benzene was also used for soil treatment [8] but found not suitable for soil treatment because the toxic materials move down to the root zone making it more hazardous.

\section{CONCLUSION}

Oil spill occurred several time along the Nigerian coast as a result of upsurge in oil exploration activities. The damages can be controlled by lime which acts as a reduction solvent that reduces the toxic deposition on the soil and fertilizers applied for soil nutrient recovery for maximum production. Chemicals can 
also be used to reclaim the polluted soil but it provides negative results because it seeps down to the root zone causing more harm than good. If combustion method is applied, the inflammation will be hazardous to organic matter of the soil.

\section{REFERENCES}

[1] R.M. Oyem, "Cutting edge oil spill recovery technology and services since 1982," 2001.

[2] I. Akunne, "Effects of Oil Spillage on Farm Land (A Case Study of Uroboh)," Department of Agricultural and Bioresources Engineering, University of Nigeria., Nsukka, Nigeria., B.Eng Project Thesis 2007.

[3] P.R. Day, "Chapter 43 - Particle fractionation and particle-size analysis," in Methods of Soil Analysis, Part 1., C.A. Black, Ed. Madison: American Society of Agronomy., 1965, pp. 545-567.

[4] C.T.I. Odu, O.F. Esuruoso, L.C. Nwoboshi, and J.A. Ogunwale, "Environmental study of the Nigerian Agip Oil Company operational areas.," in Proceedings of the soils and fresh water vegetation conference., Milan, Italy, 1985.

[5] G.N. Smith and I.G.N. Smith, Element of Soil Mechanics, 7th ed. Oxford: Blackwell Science, 1998.

[6] M.L. Jackson, Soil Chemical Analysis. New York: Prentice Hall, 1964.

[7] A. Walkey and I.A. Black, "Determination of Organic Carbon in Soil.," Soil Science, vol. 37, pp. 29-38, 1934.

[8] M. Chorom, H.S. Sharifi, and H. Motamedi, "Bioremediation of a crude oil-polluted soil by application of fertilizers," Iran J. Environ. Health Sci. Eng., vol. 7, no. 4, pp. 319-326, 2010. 